\title{
Australian Journal of

\section{Environmental impact of toxic metals on water and soil by agrochemicals, emerging pollutants and remediation methods}

\author{
Eloisa Lorenzetti ${ }^{1 *}$, Jeferson Carlos Carvalho ${ }^{1}$, Leidiane Coelho Carvalho ${ }^{1}$, Claudecir Castilho Martins ${ }^{1}$, \\ Affonso Celso Gonçalves Junior ${ }^{1}$, Juliano Tartaro ${ }^{1}$, Elizana Lorenzetti Treib ${ }^{2}$, Guilherme Borghetti Calixto ${ }^{1}$, \\ Adrieli Luisa Ritt ${ }^{1}$, Alfredo José Alves Neto ${ }^{1}$, Vanusi Camilo da Silva ${ }^{3}$
}

\author{
${ }^{1}$ State University of West Paraná - Unioeste, Marechal Cândido Rondon - Paraná - Brazil, street Pernambuco, \\ Number 1777, Zip Code: 85960-000, Box: 91, \\ ${ }^{2}$ Positive University - UP, Department of Biotechnology, Campo Comprido, Curitiba - Paraná - Brazil, street \\ Professor Pedro Viriato Parigot de Souza, Number 5300, Zip Code: 81280-330 \\ ${ }^{3}$ Unimeo - Ctesop - Marechal Cândido Rondon - Paraná - Brazil, street Rio de Janeiro, Number 600, Zip Code: \\ 85960-000
}

*Corresponding author: eloisa-lorenzetti@hotmail.com

\begin{abstract}
This review article has aimed at environment and impact of different pollutants, define, classify, analyze and cite methods of remediation according to Brazilian environmental legislation. Concerns about the preservation of the environment is extensively debated nowadays, with a view mainly to the production of effluents in agriculture, toxic metals, emerging pollutants and excessive use of agrochemicals. However, some impacts are necessary to meet the needs of economic development and social to ensure they are carried out rationally. Furthermore, application of remediation methods reduce the impact of these pollutants as small as possible. In this sense, the environment's definition, the main current impacts, the size and consequences of these and some remediation methods, as well as Brazilian environmental legislation will be addressed.
\end{abstract}

Keywords: Agriculture; Biodiversity; Environmental Law; Pollutants; Preservation.

Abbreviations: Cu_copper, Zn_zinc, Ni_nickel, Cr_chromium, Pb_lead, Cd_cadmium, Mn_Manganese.

Introduction

The environment comprehends everything that surrounds us, from natural forms to spaces and interactions. Thus, since the territorialization of societies, there is construction of the environment. Therefore, the integration of all elements that influence its constant process of transformation is important to understand. Human is always seek new relations with this environment to re-establish process of exploitation and to overcome the representation of nature. This always triggers current environmental problems.

In general, environment is not stagnant due to its dynamic relation between elements (Pereira and Curi, 2012). Since the consolidation of the capitalist system, the environmental problems have rapidly increased, especially with the globalization process, which has as main goal of homogenization of the people from all the countries of the globe (Pereira and Curi, 2012). Society increasingly demands resources and technologies to meet its needs. Man is always seeking resources, especially natural ones, causing adversities. Any change in the environment can heavily affect it. The amount of toxic waste and pollutants that cause adverse effects on biodiversity is a result of population growth, followed by new patterns of production and consumption (Espíndola and Arruda, 2008).

In order to meet economic development, some activities are indispensable. In general, they are influencing the environment, such as mining, agriculture and industry, etc. However, studies on sustainability have been focus of many research interests in recent years, mainly in the socioenvironmental area, in addition to those related to the areas of strategy, competition, management, and so forth (Sgarbi et al., 2008).

In view of the above and seeking a better understanding of the theme, this review article aims to show the main damages and remediation methods for agricultural pollution and their policies.

\section{Environment: definition and classification}

According to the national environment policy, Art. 3, I, Law $6,938 / 81$, environment is considered as the union of physical, chemical, and biological conditions, laws, influences and interactions that allows, shelters, and governs all forms of life. Ferry (2009) described that environment encompasses natural or modified forms, 
spaces, interactions, living beings, earth, atmosphere, climate, water, sound, smells and social and aesthetic factors.

In light of the above, it is not consistent to say that the environment is only what is natural, but rather that the term is very comprehensive and includes goods of artistic and historical value. Therefore, it is necessary that authorities (public and state associations) protect the environment so that these goods are ensured. This protection is necessary so that these goods can be used by all generations as stated in Art. 225 of the Federal Constitution (Brasil, 1988).

According to the National Environmental Policy, the environment can be divided into four aspects: natural, artificial, cultural and work environment. The natural or physical environment is formed by the atmosphere, biosphere's elements, water, soil, subsoil, fauna and flora, that is, areas that maintain their original formation or areas that have not been significantly altered by human (Brasil, 1988).

Under the articles 182 and 225 of the Federal Constitution, the artificial environment is constituted by the urban space that includes buildings, streets, posts, houses and public equipment like squares (Dea and Miranda, 2011).

According to article 216 of the Federal Constitution, cultural environment comprises the Brazilian cultural heritage: material, intangible and natural heritage. These are related to the action, memory and/or identity of the most diverse groups or the forms of expression. They can be scientific, artistic, and technological creations, works, objects, and cultural manifestations and sites of historical value (Dea and Miranda, 2011). It also encompasses artistic, archaeological and tourist heritage, due to their special values, and being protected by the public power, since they are of great importance for environmental law (Dantas, 2010).

The working environment is referred to a place where people develop their tasks, being able to be voluntary or remunerated. It comprises personal property and real property, which may belong to a company or corporation (Dea and Miranda, 2011).

This environment is described in section VIII of article 200 of the Federal Constitution and may be the set of climatic factors, physical or other factors that have a connection with the work of a particular person (Brasil, 1988).

\section{Environmental impacts: definition, classification and consequence}

In general, the term environmental impact is referred to the negative effects. However, there are changes that do not necessarily cause deleterious consequences to the environment, caused by natural phenomena and mainly by activities developed by man, resulting in alterations of characteristics of the physical, biotic and anthropic environment, being beneficial or adverse (Mota, 2006).

Conselho Nacional de Meio Ambiente (National Council on the Environment - CONAMA) defined environmental impact as any change in the physical, chemical and biological characteristics of the environment resulting from human activity, which may interfere directly or indirectly with society and the environment (Brasil, 2012).

According to Sanchez (2013), the environmental impacts are classified as qualitative and quantitative, according to the following criteria: (1) value criteria - positive or beneficial impact and negative or adverse impact; (2) order criteria direct and indirect impact; (3) space criteria - local impact, regional impact and strategic impact; (4) dynamics criteria temporary impact; cyclical impact; (5) plastic criteria reversible impact, irreversible impact and; (6) time criteria short-term impact, medium-term impact and long-term impact.

The development of humanity depends on technological progress. For that reason, the activities cause changes in the environment. Among them, some stand out, such as: solid waste, or garbage (Fernandes and Luna, 2013); atmospheric pollution (Mattos, 2015); mining (Mechi and Sanches, 2010); agricultural activity; emerging pollutants. Other economic activities have less impact when compared to the ones mentioned before. Some of the most common and important anthropic activities currently affecting the environment will be addressed as follows.

\section{Toxic metals}

The term "heavy metal" is used to denominate elements that have a specific mass of more than $5.00 \mathrm{~g} \mathrm{~cm}^{-3}$ or that have an atomic number of more than 20 (Gonçalves Jr et al., 2000). Elements such as $\mathrm{Cu}, \mathrm{Zn}, \mathrm{Ni}$ and $\mathrm{Cr}$ are used in biological metabolism and are considered essential, beneficial or toxic. For this purpose, the elements and their concentration in plant tissues are taken into consideration. On the other hand, $\mathrm{Pb}$ and $\mathrm{Cd}$ are not essential, instead they are toxic even at trace levels (Gonçalves Jr. et al., 2009).

The increase in the concentration of heavy metals, both soil and water tables, has anthropogenic action. The contamination of these occurs mainly by $\mathrm{Pb}, \mathrm{Cu}, \mathrm{Zn}, \mathrm{Fe}, \mathrm{Mn}$, $\mathrm{Cr}$ and $\mathrm{Cd}$, due to leaching (Kanmani and Gandhimathi, 2013). The lack of correct destination, besides the lack of previous treatment, contributes to their high mobility in the environment (Kumar and Bandyopadhyay, 2006) and contamination.

\section{Agrochemicals}

The term agrochemical is used for the categories: insecticides, acaricides, nematicides, fungicides, bactericides and herbicides. Products synthesized for the purpose of controlling living organisms are used on the target, reaching the environment (Rebelo and Caldas, 2014). In addition to the toxic effect on organisms, some of these products have potentially polluting elements or compounds, such as heavy metals, surfactants, emulsifiers, among others (Steffen et al., 2011), aggravating the consequences when used indiscriminately.

Although play an important role in modern agriculture, they may pose risks to human health and the environment. In contact with the environment, agrochemicals pass through different destinations through sorption (absorption and desorption), transformation (chemical and biological degradation) and transport (volatilization, leaching and surface transport). Beside these processes, the meteorological conditions, the location of the relief area, the presence and absence of plants and agricultural management practices can also affect the destination of agrochemicals in the environment (Steffen et al., 2011).

As a consequence of these processes, there is contamination of agricultural soils, surface water and groundwater, and 
food, presenting risks of adverse effects on terrestrial and aquatic organisms. The residues of agrochemicals present adverse behavior in the environment, depending on the concentrations in different environmental compartments (soil, water, plant and atmosphere) (Spadotto et al., 2010).

\section{Emerging pollutants}

When a chemical or material is characterized as a potential threat to human health, the environment, or lack of published health standards, it is classified as an emerging pollutant. A pollutant can also be considered "emerging" due to the discovery of a new source or a new way of contact with humans (Epa, 2013).

Emerging pollutants are also the result of anthropogenic action, such as pharmaceutical compounds and personal use products, industrial by-products, steroids and hormones (Montagner et al., 2017). They stand out as contaminants of the agroecosystem with the intensification of production and disposal in the environment without being treated.

Human or veterinary drugs are released into the environment through excreta (Valcárcel et al., 2011) or improper disposal of overdue medicine (Falqueto et al., 2010; Bellan et al., 2012). They act in specific ways in organisms.

Some drug products have been identified as lethal to vultures, such as diclofenac (Naidoo et al., 2009). Furthermore, the reproduction rate of Daphnia magna and Moinama crocopa species in concentrations of 25 a $50 \mathrm{mg} \mathrm{L}^{-}$ ${ }^{1}$ of diclofenac was reduced after explosion to this drug for 3 months (Lee et al., 2011).

\section{Analysis and solution for environmental problems}

The damage to the environmental balance presents itself in several ways. It is impacted by the needs of society to survive, such as food production, increasing deforestation, contaminating soil, water and the atmosphere among other. This helps the global warming, impacting on social and economic development worldwide presenting incalculable, and in many cases irreversible risks (Borinelli, 2011).

Although the environmental problems have been known for several decades, only in the last few years, they have become major concern and the society has payed attention to the impact of these problems, especially in developed countries. In developing countries e.g. Brazil, there is no perception of the dimension and/or public knowledge of the importance of this issue, due to the lack of public policies (Silva and Travassos, 2008).

One of the steps to define the environmental problem and proposing solution is to know the problem and its dimension, leading to adequate remediation and reduction of impacts (Silva and Travassos, 2008). To facilitate the analysis of impacts, some methods have been developed, such as the environmental impact assessment (AIA). Some technical criteria and general guidelines for the elaboration of the Environmental Impact Study (Estudo de Impacto Ambiental - EIA) and respective Environmental Impact Report (Relatório de Impacto ao Meio Ambiente - RIMA) were established (Brasil, 2012).

The environmental impact assessment and the environmental impact study are important tools for management and protection of environment. Any project that could cause harm to the environment is analyzed according to the damages caused. It is carried out by a multidisciplinary team and has a diagnosis, description, analysis and evaluation on the actual and potential environmental impacts (Brasil, 2012). These analyzes define and obtain the risks before, during and after a project's implementation (Sánchez, 2013).

In turn, the environmental impact report reflects the results of the AIA and the EIA, and should be formulated objectively, easily understood, using illustrations with maps, charts and graphics (Brasil, 2012).

Usually, the solution of a problem implies on the solution of other problems related to the first one. In some cases, these are of irreversible nature, such as environmental crisis of 1950 that triggered the creation of laws by institutions and programs that regulate and ease these problems (Borinelli, 2011). Considering these problems, some remediation methods are observed to reduce the impacts.

Among the remediation methods, bioremediation can be used. This method usually uses microorganisms for decontamination, phytoremediation and plants for remediation (Coutinho et al., 2015). Schwantes et al. (2013) mentioned the use of flocculants to reduce the volume of agricultural effluents, also emphasizing the frequency and quantity applied. Another method used in case of contamination by heavy metals is the use of adsorbents (Schwantes et al., 2015).

Another important factor for the use of swine effluents are the physical and chemical characteristics of the soil. Management for sandy soils with lower anion exchange capacity and low organic matter are more prone to leaching losses, as opposed to well-structured clay soils with high organic matter content (Brady and Weil, 2013). Organic matter is also important in agrochemical-contaminated soils helping the adsorption and decomposition of pollutants.

Some agricultural residues have a certain degree of complexity. For instance in many cases, swine manure contains contaminants such as heavy metals, if applied in large concentrations. Their frequent use increase risk of contamination and alteration of the environment by inappropriate planning and usage policies (Schwantes et al., 2013).

For the removal of heavy metals from agricultural effluents, the use of adsorbents may be employed. This method uses material with adsorptive capacity, wherein the solid particle (adsorbent) has a surface on which its unbalanced forces are available to adsorb elements of the liquid phase. This adsorption may occur chemically and/or physically (Ramalho, 1977). An example of this is the use of mesocarp of macadamia chemically modified by sodium hydroxide, presenting significant results in adsorbing metals such as $\mathrm{Pb}^{2+}$ and $\mathrm{Cr}^{3+}$ (Vilas Boas et al., 2016).

Another major problem in Brazilian agriculture is the indiscriminate use of agrochemicals, resulting in impacts on the environment. Among the methods to reduce this impact, some alternatives such as the biological control and application of non-toxic compounds can be mentioned (Borsoi et al., 2014).

Another alternative is the use of plants such as Eichhornia crassipes and Salviniaa uriculata. They are alternatives for the remediation of water. They are able to improve parameters such as water turbidity, nitrogen concentration and chemical oxygen demand. The only care that must be 
taken is the removal of the plants before their senescence, to avoid the return of these components to the environment (De Castro, 2017).

A recent problem that has been investigated in Brazil is the emerging pollutants. The report identified contaminants such as atenolol, caffeine, carbamazepine, diclofenac, ibuprofen, naproxen, propranolol, triclosan and the hormones estrone, 17- $\beta$-estradiol and $17-\alpha$-ethynylestradiol (Sousa et al., 2014). They are found in river, sea and water supply, as a result of the use of medication in animals and people. It can be remedied mainly by degradation by microorganisms such as bacteria (Dawas-Massalha et al., 2014; Kassotaki et al., 2016).

\section{Legislation}

In 1981, the National Environmental Policy Act (Law $6.938 / 81$ ) was raised. In the article $3^{\text {rd }}$ it says: "Environment is the set of conditions, law and interaction of physical, chemical and biological order that allows, shelters and refers to life in all forms". This law promotes clear definitions for the environment, qualifies the actions of modifying agents and provides mechanisms to ensure environmental protection (Brasil, 1988).

The Federal Constitution of 1988, Article 225, provides a threefold responsibility for environmental aggressors with civil, administrative and penal sanctions, linked to the obligation to repair damages caused to the environment. In addition, public authorities themselves can be blamed for the omission of supervision (Brasil, 1988). It also defines the "polluter pays" principle in Article 3, section IV, which states: "polluter is any person or industry, whether public or private, directly or indirectly responsible for an activity that causes environmental damage".

Fiorillo (2013) declared that the polluter principle has two scopes to be observed. One of them has the objective of avoiding environmental damages, demonstrating a preventive character. The other demonstrates a repressive character, because if the damage occurs it aims to repair it. So, the reconstitution of the environmental picture must be performed $a$ priori so that it is as close as possible to what it was before the damage was done.

In the agricultural sector, the CONAMA resolution $\mathrm{n} 0302$ March 2002, establishes the parameters, definitions and limits of the Area of Permanent Preservation of Artificial Reservoirs and the System of Use of the Environment. The CONAMA resolution no303 of March/May 2002 complements Resolution $\mathrm{n} 0302$ and provides the new parameters, definitions and limits of permanent preservation areas. The CONAMA Resolution $\mathrm{n}-425$ of May 2010 sets forth criteria for the characterization of sustainable agricultural activities and sustainable enterprises of the family farmer, rural family entrepreneur, and of the traditional people and communities as of social interest for the production, intervention and recovery of Area of Permanent Preservation and others of limited use.

\section{Waste}

Law no12,305/10 of the National Policy on Solid Waste classifies waste according to origin and hazardousness. Due to their origin, they can be urban solid waste and from agroforestry activities. Regarding their hazardousness, they are classified as hazard (Class 1: contaminants and toxic), non-inert (Class 2: possibly contaminants), inert (Class 3 : non-contaminating), in addition to considering the aspects related to generation, segregation, packaging, collection, storage, transportation, treatment and final disposal, as well as protection of public health (Brasil, 2012).

The CONAMA Resolution $\mathrm{n} 0420$ of December 2009 provides criteria for the soil quality upon the presence of chemical substances and establishes guidelines for the environmental management of areas contaminated by these substances because of human activities. In general, this resolution demonstrates preventive concern to ensure and maintain the quality and functionality of the soil (Brasil, 2012).

The Law no 9,433/97, National Water Resources Policy, creates the National Water Resources Management System based on the following fundamentals: water is a public domain property; water is a limited natural resource with economic value. In times of scarcity, its priority uses are consumption by humans and animals. The management of water resources must always provide the use of water. The drainage basin is the territorial unit for the implementation of the National Water Resources Policy. The management of water resources must be decentralized and have the participation of public authorities, users and communities. This law aims to ensure the current and future generations the necessary availability of water, in quality standards appropriate to the respective uses (Brasil, 1997).

Finally, it is worth mentioning that Federal Law $\mathrm{n}-605 / 98$, on Environmental Crimes provides guidelines for criminal and administrative sanctions for conducts and activities that cause environment damage, and other provisions. It describes penalty applications, seizure of products and instruments of infraction of the action and of the penal process, of the crimes against the environment, natural and artificial, as well as crimes against the cultural heritage, etc.

\section{Conclusions}

It is notable that the search for production methods that meet the needs of the growing world population are indispensable. Thereby, it becomes inherent that environmental impacts occur to meet the needs of economic and social development. However, it is essential that these impacts occur in a rational way, and that remediation methods are used, contributing to the least impact. Cases of environmental impacts of different natures are common nowadays in the most diverse activities. In spite of that, recovery of the environmental damage is necessary, whereas those responsible are brought before the courts and charged with the penalties imposed by the current legislation. Nevertheless, the effectiveness of these actions depends on the supervisory authorities. However, it is necessary that these authorities have ideal structure and human resources to carry out their assignment with quality.

\section{References}

Bellan N, Pinto TJA, Kaneko TM, Moretto LD, Santos Junior N (2012) Critical analysis of the regulations regarding the disposal of medication waste. Braz J Pharm Sci. 48 (3): 507 518.

Borinelli B (2011) Problemas ambientais e os limites da política ambiental. Serv Soc Rev. 13 (2): 63-84. 
Borsoi A, Santos PRR, Taffarel LE, Gonçalves Jr AC (2014) Agrotóxicos: histórico, atualidades e meio ambiente. Acta Iguazu. 3 (1): 86-100.

Brady NC, Weil RR (2013) Elementos da natureza e propriedades do solo. 3 ed. Porto Alegre - RS, Bookman Editora Ltda, $683 \mathrm{p}$.

Brasil (1997) Lei $n^{\circ} 9.433$ de 8 de janeiro de 1997. Política Nacional dos Recursos Hídricos.

Brasil. (2012) Conselho Nacional Do Meio Ambiente (Conama). Resoluções Conama: Resoluções vigentes publicadas entre setembro de 1984 a Janeiro de 2012. Ministério do Meio Ambiente. Brasília: Ibama, 1126 p.

Brasil (1988) Constituição da República Federativa do Brasil, Brasília, DF: Senado Federal: Centro Gráfico, 1988.

Coutinho PWR, Cadorin DA, Noreto LM, Gonçalves Jr AC (2015) Alternativas de remediação e descontaminação de solos: biorremediação e fitorremediação. Nucleus. 12 (1): 59-68.

Dantas FS (2010) Guerra e Paz: uma análise da evolução das normas internacionais de proteção ao patrimônio cultural. Rev Direi Const Inter. 18 (71): 85-102.

Dawas-Massalha A, Gur-Reznik S, Lerman S, Sabbah I, Dosoretz CG (2014) Co-metabolic oxidation of pharmaceutical compounds by a nitrifying bacterial enrichment. Bioresour Technol. 167: 336-342.

De Castro GM, Schwantes D, Gonçalves Jr, AC, Richart A, Veiga TG, Rosenberger AG (2017) Treatment of dairy effluents in wetlands systems with floating aquatic macrophytes. Rev Ciênc Ambient. 11 (2): 25-37.

Dea CRD, Miranda FSMP (2011) Aspectos Jurídicos do Direito Ambiental e a Responsabilidade Civil por Danos Ambientais. Ver. Eletrônica Direito Justiça e Cidadania. 2 (1): 01-62.

Epa US Environmental Protection Agency (2013) Emerging Contaminants and Federal Facility Contaminants of Concern. Federal Facilities Restoration and Reuse Office (FFRRO). < https://www.epa.gov/fedfac>.

Espíndola MAJ, Arruda DO (2008) Desenvolvimento sustentável no modo de produção capitalista. Ver. Visões. 1 (4): 1-11.

Falqueto E, Kligerman DC, Assumpção RF (2010) Como realizar o correto descarte de resíduos de medicamentos?. Ciênc. saúde coletiva. 15 (Supl. 2): 3283-3293.

Fernandes LG, Sansolo DG (2013) Percepção ambiental dos moradores da cidade de São Vicente sobre os resíduos sólidos na Praia do Gonzaguinha, SP, Brasil. J Integrated Coastal Zone Management. 13 (3): 379-389.

Ferry L (2009) A Nova Ordem Ecológica: a árvore, o animal e o homem. Tradução de Tejane Janowitzer. Rio de Janeiro. $252 \mathrm{p}$.

Fiorillo CAP (2013) Curso de Direito Ambiental Brasileiro. 14 ed. São Paulo: Saraiva. 961 p.

Gonçalves Jr ACG, Selzlein C, Nacke H (2009) Uso de biomassa seca de aguapé (Eichornia crassipes) visando a remoção de metais pesados de soluções contaminadas. Acta Scientiarum. Technology. 31 (1): 103-108.

Gonçalves Junior AC, Luchese EB, Lenzi E (2000) Avaliação da fitodisponibilidade de cádmio, chumbo e crômio em soja cultivada em Latossolo Vermelho escuro tratado com fertilizantes comerciais. Quím Nova, 23 (2): 173-177.
Kanmani S, Gandhimathi R (2013) Assessment of heavy metal contamination in soil due to leach at emigration from an open dumping site. R. Appl Water Sci, 3 (1): 193205.

Kassotaki E, Buttiglieri G, Ferrando-Climent L, RodriguezRoda I, Pijuan M (2016) Enhanced sulfamethoxazole degradation through ammonia oxidizing bacteria cometabolism and fate of transformation products. Water Res. 94: 111-119.

Kumar U, Bandyopadhyay M (2006) Sorption of cadmium from aqueous solution using pretreated rice husk. Bioresour Technol. 97 (1): 104-109.

Lee J, Ji K, Kho YL, Kim P, Choi K (2011) Chronic exposure to diclofenac on two fresh water cladocerans and Japanese medaka. Ecotoxicology and Environmental Safety. 74 (5): 1216-1225.

Mattos CE (2015) Poluição do ar em áreas centrais urbanas. Rev Científica Unilago. 1: 1-8.

Mechi A, Sanches DL (2010) Impactos ambientais da mineração no Estado de São Paulo, Estudos Avançados. 24: 209-220.

Montagner CC, Vidal C, Acayaba R (2017) Contaminantes emergentes em matrizes aquáticas do Brasil: cenário atual e aspectos analíticos, ecotoxicológicos e regulatórios. Quím nova, 40 (9): 1094-1110.

Mota S (2006) Estudo de impacto ambiental. In: Introdução à engenharia ambiental. $4^{\text {a }}$ ed., Rio de janeiro: ABES, cap. 8, p. 281- 310.

Naidoo V, Wolter K, Cuthbert R, Duncan N (2009) Veterinary diclofenac threatens Africa's endangered vulture species. Regulatory Toxicology and Pharmacology, 53: 205-208.

Pereira SS, Curi RC (2012) Meio Ambiente, Impacto Ambiental e Desenvolvimento Sustentável: Conceituações Teóricas sobre o Despertar da Consciência Ambiental. REUNIR, 2 (4): 35-57.

Ramalho RS (1977) Introduction to waste water treatment processes. New York, p. 705.

Rebelo RM, Caldas ED (2014) Avaliação de risco ambiental de ambientes aquáticos afetados pelo uso de agrotóxicos. Quím. Nova, 37 (7): 1199-1208.

Sánchez LE (2013) Avaliação de impacto ambiental: Conceitos e métodos. São Paulo, oficina de texto, $2^{\text {a }}$ ed., $580 \mathrm{p}$.

Schwantes D, Da Costa PF, Gonçalves EDV, Mattiello V, Gonçalves Jr AC (2013) Impacto ambiental da suinocultura e uso de floculantes como alternativa no tratamento de dejetos suínos: um estudo de caso. Cultivando o Saber. 6 (1): 162-172.

Schwantes D, Gonçalves Jr, AC, Miola AJ, Coelho GF, Dos Santos MG, Leismann EAV (2015) Removal of CU (II) and Zn (II) from water with natural adsorbents from cassava agroindustry residues. Acta Scientiarum. 37 (3): 409-417.

Sgarbi VS, Lima MTA, Santos CFSO, Falcão MC (2008) Os jargões da sustentabilidade: uma discussão a partir da produção científica nacional. Engema, $10 \mathrm{p}$.

Silva LS, Travassos L (2008) Problemas ambientais urbanos: desafios para a elaboração de políticas públicas integradas. Cadernos Metrópole, 19: 27-47.

Sousa DNR, Mozeto AA, Carneiro RL, Fadini PS (2014) Electrical conductivity and emerging contaminant as markers of surface freshwater contamination by wastewater. Sci Total Environment. 484: 19-26. 
Spadotto CA, Scorza Jr RP, Dores EFGC, Gebler L, Moraes DAC (2010) Fundamentos e aplicações da modelagem ambiental de agrotóxicos. Campinas, (Embrapa Monitoramento por Satélite. Documentos, 78, $46 \mathrm{p}$.

Steffen GPK, Steffen RB, Antoniolli ZI (2011) Contaminação do solo e da água pelo uso de agrotóxicos. Tecno-lógica, 15 (1): 15-21.

Valcárcel $\mathrm{Y}$, González Alonso S, Rodríguez-gil JL, Romo Maroto R, Gil A, Catalá M (2011) Analysis of the presence of cardiovascular and analgesic / anti inflammatory / antipyretic pharmaceuticals in river- and drinking-water of the Madrid Region in Spain. J Chemosphere, 82 (7): 10621071.
Vilas Boas N, Casarin J, Gerola GP, Tarley CRT, Caetano J, Gonçalves AC, Dragunski DC (2016) Evaluation of kinetic and thermodynamic parameters in adsorption of lead $\left(\mathrm{Pb}^{2+}\right)$ and chromium $\left(\mathrm{Cr}^{3+}\right)$ by chemically modified macadamia (Macadamia integrifolia). Desalination and Water Treatment, 57 (38): 17738-17747. 